\title{
Potential of Cry1Ac from Bacillus thuringiensis against the tomato pinworm, Tuta absoluta (Meyrick) (Gelechiidae: Lepidoptera)
}

Sandeep Kumar Jalapathi ${ }^{1 *}$, J. Jayaraj ${ }^{1}$, M. Shanthi ${ }^{1}$, M. Theradimani ${ }^{2}$, Balasubramani Venkatasamy ${ }^{3}$, S. Irulandi ${ }^{4}$ and S. Prabhu ${ }^{5}$

\begin{abstract}
The tomato pinworm, Tuta absoluta (Meyrick) (Gelechiidae: Lepidoptera), is an introduced serious pest of tomato in India. Management of this insect pest mainly relies on insecticides because of its high infestation levels on all plant parts and life stages of tomato crop. This laboratory study investigated the efficacy of Cry1Ac protein of Bacillus thuringiensis against T. absoluta. The $\mathrm{LC}_{50}$ and $\mathrm{LC}_{95}$ values for $2 \mathrm{nd}$, $3 \mathrm{rd}$, and 4 th larval instars were $0.12,0.27$, and $0.43 \mu \mathrm{g} / \mathrm{ml}$ and $0.63,0.71$, and $2.64 \mu \mathrm{g} / \mathrm{ml}$, respectively. Experimental results showed that Cry $1 \mathrm{Ac}$ is effective against different larval instars of tomato pinworm.
\end{abstract}

Keywords: Bacillus thuringiensis, Tuta absoluta, Bioassay, Cry1Ac toxin

\section{Background}

The tomato pinworm (TPW), Tuta absoluta (Meyrick) (Gelechiidae: Lepidoptera), is an important pest of tomato in India. It is a micro-lepidopteran and oligophagous pest native of South America. It was described by E. Meyrick in Peru during 1917. Tomatoes are grown both under greenhouse and open field conditions. One of the major limiting factors in tomato production is $T$. absoluta, a global invasive pest. In India, this pest was initially observed in Pune, Maharashtra, in both polyhouse and open field tomatoes in October 2014. The maximum level of infestation causes $80-100 \%$ yield loss (Tropea Garzia et al. 2012; Shashank et al., 2015).

Among several management options, more reliance on insecticides may not be viable as they provide ephemeral benefits, often with adverse side effects. Evolution of pesticide-resistant strains has been reported in South

\footnotetext{
*Correspondence: sndpkmr007@gmail.com

'Department of Agricultural Entomology, Agricultural College and Research Institute, Madurai 625104, India

Full list of author information is available at the end of the article
}

America and Europe due to repeated and heavy use of pesticides (Silva et al., 2011). One alternative to insecticides is the use of biological insecticides like Bacillus thuringiensis $(B t)$ that expresses insecticidal crystal (CRY) proteins during sporulation phase of its growth cycle. These crystal proteins, which are sequestered in bacteria as crystalline inclusions, mediate specific pathogenicity against insects. It has been found to be a very effective, environmentally safe, and insect-specific biopesticide. Toxicity of $B t$ spray-able formulations, which are considered highly effective, selective, safe, and compatible in integrated pest management, is largely due to Cry toxins (Sanyasi and Govind, 2011).

Alternatives like biological preparations from $B t$ reduced T. absoluta damage up to $90 \%$, but showed poor field persistence and need for repeated applications (GonzalezCabrera et al. 2011). Bt var. kurstaki still exhibits a satisfactory efficacy against $T$. absoluta larval infestations in Spanish outbreaks (Sanda et al., 2018). According to the different varieties, $B t$ is highly specific to some insect orders including Lepidoptera, Diptera, and Coleoptera. Bt 
formulates are very effective against $T$. absoluta under laboratory, greenhouse, and field conditions (Ghazwan et al., 2017). The present study was undertaken to evaluate the potential of $B t$ toxin Cry1Ac against larval instars of T. absoluta under laboratory conditions.

\section{Materials and methods}

Purified Cry1Ac toxin was obtained from the Centre for Plant Molecular Biology and Biotechnology (CPMB\& B), Tamil Nadu Agricultural University (TNAU), Coimbatore, India. Original JM (Jockey Mango) 103 E. coli strain expressing Cry1Ac gene was originally obtained from Dr. Neil Crickmore's Lab, University of Sussex, UK, and Cry1Ac was extracted as described by Sayyed et al. (2000). Cry1Ac toxin was stored at $-20{ }^{\circ} \mathrm{C}$.

All the experiments were conducted at Horticultural College \& Research Institute, Periyakulam, TNAU. The culture of tomato pinworm was maintained on tomato plants (PKM1) for 2 generations prior to use in leaf dip bioassay studies under laboratory conditions. The toxin dilutions were freshly prepared for each assay (Dakshina and Gary, 2003). For $\mathrm{LC}_{50}$ estimation, bioassay studies were conducted by different concentrations. The concentrations of $B t$ protein were prepared separately for 2nd instar $(0.05,0.10,0.15,0.20,0.25$, and $0.30 \mu \mathrm{g} / \mathrm{ml})$, 3rd instar $(0.15,0.20,0.25,0.30,0.35$, and $0.40 \mu \mathrm{g} / \mathrm{ml})$, and 4th instar $(0.10,0.20,0.30,0.40,0.50$, and $0.60 \mu \mathrm{g} /$ $\mathrm{ml}$ ) in separate experiments. All concentrations were made up to a total volume of $25 \mathrm{ml}$ in a glass beaker. To determine $\mathrm{LC}_{50}$ values for toxic concentrations in the exposure experiments, preliminary bioassays were conducted. Different known concentrations of Cry1Ac protein were used and prepared in $0.02 \%$ Tween 20 , using double distilled water.

Fresh leaves were placed in a plastic container $(2-\mathrm{cm}$ diameter and $3-\mathrm{cm}$ height) into which $2 \%$ melted agar (allowed to cool) was added and then leaf discs (1-cm diameter) were placed to maintain turgidity, and individual larvae per container were released. Pot-cultured 45day-old plant tomato (PKM1) leaf discs were immersed in each suspension for $1 \mathrm{~min}$, and then air dried. Groups of $10 \mathrm{~T}$. absoluta larvae (2nd, 3rd, and 4th separately), pre-starved for $4 \mathrm{~h}$, were allowed to feed on the treated leaves. For untreated check, the larvae were fed on untreated leaves (leaves dipped in $0.02 \%$ Tween 20 and air dried). A minimum of 30 insects per concentration were used; each concentration had 3 subsets as replicates. Each assay was performed 2-3 times. All bioassays were carried out under a controlled environment at $25 \pm 5{ }^{\circ} \mathrm{C}$ and $80 \%$ RH with a $12: 12 \mathrm{~h}$ (D:L).

\section{Data analysis}

Mortality rates of larvae at 24-h intervals for 5 days after initiation of the experiment were recorded. Any larva failed to move when touched repeatedly was considered dead. Corrected mortality percentages were worked out, using Abbott's formula (Abbott, 1925), and subjected to probit analysis (Finney, 1971) from EPA Probit Analysis Program (version 1.5).

\section{Results and discussion}

The results of the probit regression analysis of concentration-response mortality data for the bioassays of Cry1Ac to $T$. absoluta were recorded. The slope values of different larval instars varied significantly, indicating variability in the susceptibility to Cry1Ac among the larval stages. T. absoluta showed variable responses to Cry1Ac as reflected in the $\mathrm{LC}_{50}$ values for $2 \mathrm{nd}$, $3 \mathrm{rd}$, and 4th instar larvae. Cry1Ac showed toxicity to all larval instars of pinworm. Based on the concentration mortality response to Cry1Ac, the $\mathrm{LC}_{50}$ and $\mathrm{LC}_{95}$ values for 2nd, 3rd, and 4th instars were $0.12,0.27$, and $0.43 \mu \mathrm{g} / \mathrm{ml}$ and $0.63,0.71$, and $2.64 \mu \mathrm{g} / \mathrm{ml}$, respectively (Table 1 ). The susceptibilities of different larval instars of tomato pinworm to Cry1Ac protein produced by $B t$ var. kurstaki were presented in Fig. 1. At $\mathrm{LC}_{50}, 50 \%$ mortality was observed in the 3rd day of treatment, in all the instars tested. Based on the present study, it is evident that all the larval instars of the pest were susceptible to the Cry1Ac of $B t$. The results indicated that susceptibility of larvae decreased with larval developmental stage.

Variations in susceptibility of tomato pinworm depend on the age of the insect, and susceptibility decreased with the age of the insect. Control measures are sometimes ineffective because larvae feed inside the galleries formed from mesophyll tissues (Desneux et al., 2011).

Obtained results are in accordance with Dakshina and Gary (2003) who reported that CRY I toxin was toxic to tomato pinworm, Keiferia lycopersicella, with $\mathrm{LC}_{50}=$ 17.68 to $56.00 \mu \mathrm{g} / \mathrm{ml}$ in Florida, with 3.17-fold difference (lab population; Homestead $\mathrm{LC}_{50}$ value 17.68 with resistant population Guasava 1 with $\mathrm{LC}_{50}$ value 56.00). Similarly, when Helicoverpa armigera (Hub.) was continuously exposed to Cry1Ac toxin under laboratory conditions, resistance has been developed (Kranthi et al., 2000) as well, against the beet armyworm, Spodoptera exigua (Hubner) (Muhammad et al., 2019). The present results are in accordance with Kannan and Uthamasamy (2006) who reported the $\mathrm{LC}_{50}$ values were $0.119 \mu \mathrm{g} / \mathrm{ml}$ for $H$. armigera. Susceptibility to Cry1Ac for $H$. armigera geographically varied between India, America, and China.

However, a repeated and intensive use of $B t$ formulations may lead to resistance in the case of Plutella xylostella (Tabashnik and Carriere, 2017). The use of biopesticides is one effective way of coping with insect pests. Of the total production of biopesticides, entomopathogenic bacteria (mostly $B t$ ) amount to $90 \%$. Bt has 
Table 1 Toxicity of Cry1Ac protein from Bacillus thuringiensis to 2nd, 3rd, and 4th larval instars of tomato pinworm, Tuta absoluta

\begin{tabular}{|c|c|c|c|c|c|c|c|c|c|}
\hline \multirow[t]{2}{*}{ Larval stage } & \multirow[t]{2}{*}{ Slope } & \multirow[t]{2}{*}{$\mathrm{SE}^{\mathrm{a}}$} & \multirow[t]{2}{*}{$x^{2 b}$} & \multirow{2}{*}{$\begin{array}{l}\mathrm{LC}_{50} \\
(\mu \mathrm{g} / \\
\mathrm{ml})\end{array}$} & \multicolumn{2}{|c|}{ Confidence limits (95\%) } & \multirow{2}{*}{$\begin{array}{l}\mathrm{LC}_{95} \\
(\mu \mathrm{g} / \\
\mathrm{ml})\end{array}$} & \multicolumn{2}{|c|}{ Confidence limits (95\%) } \\
\hline & & & & & Lower limit & Upper limit & & Lower limit & Upper limi \\
\hline Second instar & 2.13 & 0.56 & 0.10 & 0.12 & 0.07 & 0.16 & 0.63 & 0.40 & 1.72 \\
\hline Third instar & 3.96 & 1.12 & 0.34 & 0.27 & 0.22 & 0.33 & 0.71 & 0.49 & 2.18 \\
\hline Fourth instar & 2.10 & 0.63 & 0.17 & 0.43 & 0.30 & 0.65 & 2.64 & 1.29 & 37.4 \\
\hline
\end{tabular}

${ }^{\mathrm{a}}$ Standard error, ${ }^{\mathrm{b}}$ chi-square test

been commercially used in the biological control of insect pests for the last 4 decades. Bt strains can produce toxic compounds of numerous chemical structures and properties. Selectivity of $B t \delta$-endotoxins against the larvae of target insects was documented earlier (Stepanova et al., 1996). As Cry1Ac was toxic to all the instars of TPW, yield loss due to this pest can be efficiently reduced by $B t$-based formulations. From the bioassay $\mathrm{LC}_{50}$ values obtained for all instars, it is evident that the populations of Tamil Nadu were enough susceptible for effective control. Further, if we can establish the quantity of $B t$ toxin required, the information will be useful, while developing transgenic tomato crops, it will give an idea about the required level of $B t$ toxin expression.

$B t$ products/ commercial formulations are environmentally safe and provide good yield without any chemical residues and exhibited satisfactory efficacy against T. absoluta. Srinivasan and Dilipsundar (2019) reported that Dipel (Bt var. kurstaki) was very effective against tomato pinworm with $78.67 \%$ reduction in larval population by field evaluation. Youssef and Hassan (2013) reported that the commercial formulation "Protecto" was highly effective against tomato pinworm with 96.7\% mortality and other $B t$ isolates with 93.3, 90, 86.7, and $80 \%$ mortalities. Gowtham et al. (2018) stated that standard $B t$ strain (HD1) and $B t$ isolate KGS2 showed 95 and $100 \%$ mortality against tomato pinworm. Hatice et al. (2017) transferred a modified Bt Cry1Ac gene to tomato plants through Agrobacterium tumefaciens-mediated transformation. Cry1Ac-expressed tomato plants resulted in mortality rates at $38-100 \%$ depending on the transgenic line. In infested leaves, gallery formation was reduced to $57-100 \%$ of transgenic plants. This is the first report on the development of transgenic tomato plants resistant to T. absoluta.

Bioassays of the viable biocide in the laboratory showed high efficacy in dropping the damage caused by various larval instars of $T$. absoluta at different concentrations compared to untreated control. First and 2nd instars recorded the highest mortality rates, while it was less in 3rd and 4th larval instars. Quite a few pest instars were found to be susceptible to $B t$ to a different extent (Giustolin et al., 2001). Also, in the later instars, the lowest mortality rate was probably due to increased maturation immunity of the larvae. On the other hand, the early instars suffered from higher mortality compared to the late instars. The capacity of Bt subsp. kurstaki as commercial biocide in reducing pests of economic importance is well known as a key part of IPM programs (Roh et al., 2007).

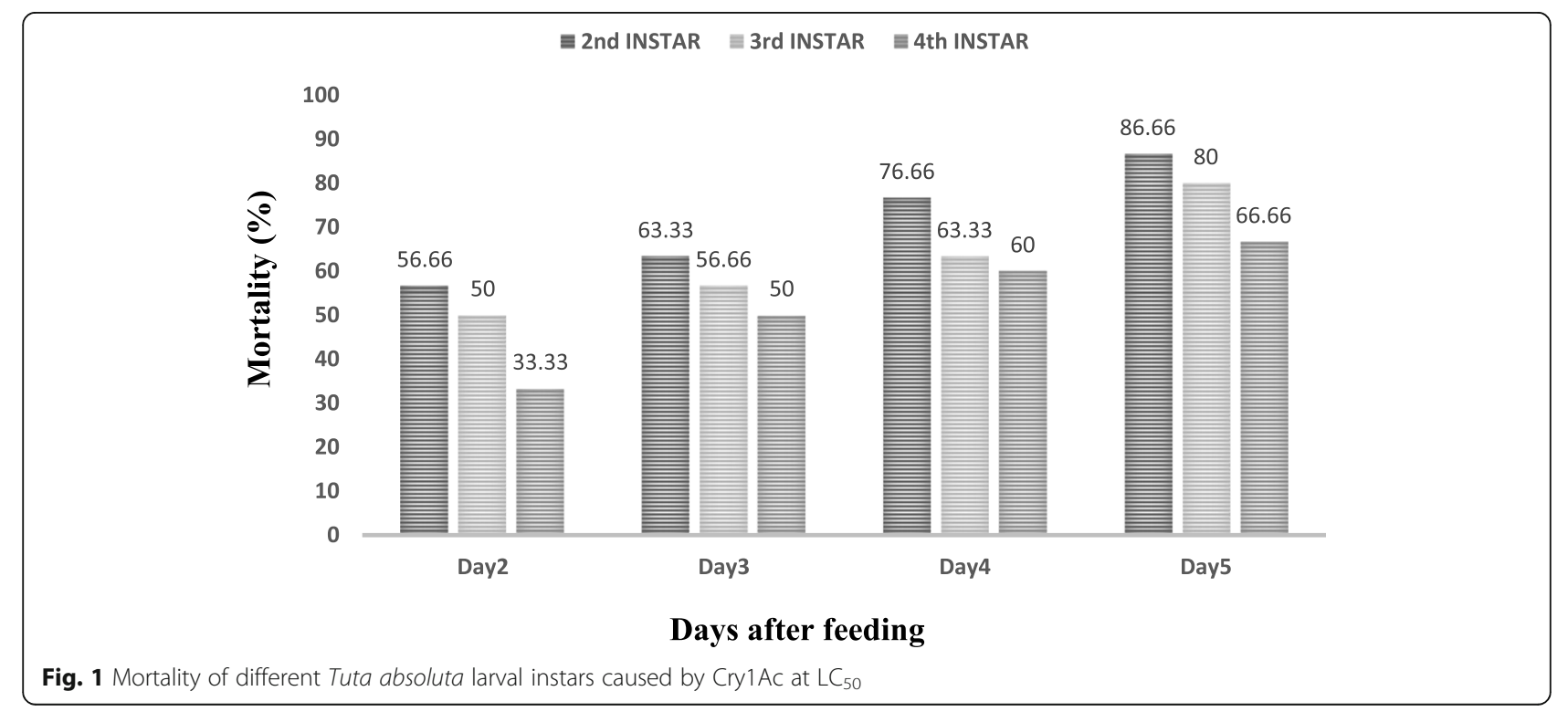




\section{Conclusion}

Different instars of $T$. absoluta to Cry1Ac protein produced by $B t$ var. kurstaki showed susceptible reactions. $\mathrm{LC}_{50}$ values for different instars varied significantly, indicating variability in the susceptibility among the instars to the Cry1Ac. This information may establish a base for selecting Bt Cry1Ac to be used for the control of tomato pinworm.

\section{Abbreviations}

TPW: Tomato pinworm; T. absoluta: Tuta absoluta; Bt: Bacillus thuringiensis

\section{Acknowledgements}

The authors acknowledge the Centre for Plant Molecular Biology and Biotechnology (CPMB\& B), Tamil Nadu Agricultural University (TNAU), Coimbatore, India.

\section{Authors' contributions}

BV performed the idea of this article, and SKJ and BV wrote the manuscript. $J J$ and MS participated in writing the manuscript and statistical analysis. MT, $\mathrm{SI}$, and SP contributed the material and helped in the maintenance of Tuta absoluta, while all authors equally did the bioassay experiments. The authors read and approved the final manuscript.

\section{Funding}

This work was not supported by any funding body.

Availability of data and materials

Not applicable

\section{Ethics approval and consent to participate}

Not applicable

\section{Consent for publication}

I agree to publish this paper in the EJBPC.

\section{Competing interests}

The authors declare that they have no competing interests.

\section{Author details}

${ }^{1}$ Department of Agricultural Entomology, Agricultural College and Research Institute, Madurai 625104, India. ²Department of Plant Pathology, Agricultural College and Research Institute, Madurai 625104, India. ${ }^{3}$ Department of Rice, Agriculture College and Research Institute, Coimbatore 641003, India. ${ }^{4}$ Department of Fruit Crops, Horticulture College and Research Institute, Periyakulam 625604, India. ${ }^{5}$ Department of Plant Protection, Horticulture College and Research Institute, Periyakulam 625604, India.

Received: 13 April 2020 Accepted: 18 June 2020

Published online: 26 June 2020

\section{References}

Abbott WS (1925) A method for computing the effectiveness of an insecticide. J Econom Entom 18:265-267

Dakshina RS, Gary LL (2003) Toxicity of Bacillus thuringiensis CRY1-type insecticidal toxin to geographically distant populations of tomato pinworm. Flor Entomol 86(2):222-224

Desneux N, Luna MG, Guillemaud AU (2011) The invasive South American tomato pinworm, Tuta absoluta, continues to spread in Afro-Eurasia and beyond: the new threat to tomato world production. Pes Manag Sci 84:403-408

Finney DJ (1971) Probit analysis, 3rd edn. Cambridge University Press, Cambridge, UK

Ghazwan A, Ahmad A, Reza T (2017) Evaluation of Bacillus thuringiensis to control Tuta absoluta (Meyrick) (Lepidoptera:Gelechiidae) under laboratory conditions. Agri Scien 8:591-599

Giustolin TA, Vendramim JD, Alves SB, Vieira SA, Pereira RM (2001) Susceptibility of Tuta absoluta (Meyrick) (Lepidoptera:Gelechiidae) reared on two species of
Lycopersicon to Bacillus thuringiensis var. kurstaki. J Appl Entomol 125(9-10):551-556

Gonzalez-Cabrera J, Molla O, Monton H, Urbaneja A (2011) Efficacy of Bacillus thuringiensis (Berliner) in controlling the tomato borer, Tuta absoluta (Meyrick) (Lepidoptera: Gelechiidae). Bio Cont 56:71-80

Gowtham V, Kannan M, Senthi Kumar M, Soundararajan RP (2018) Isolation and characterization of indigenous Bacillus thuringiensis, Berliner from animal ordure effective against South American Tomato pinworm, Tuta absoluta (Meyrick). Pest Manag in Horti Eco 24(1):1-7

Hatice S, Fathih G, Nedim M, Sami D, Anne F (2017) Cry1Ac-mediated resistance to tomato leaf miner (Tuta absoluta) in tomato. Pla Cel Tiss Org Cult 131(1):65-73

Kannan M, Uthamasamy S (2006) Effects of sublethal doses of Bacillus thuringiensis $\delta$-Endotoxin Cry $1 \mathrm{Ac}$ on the developmental performance of the cotton bollworm, Helicoverpa armigera (Hubner). Biopest Intern 2(1):51-59

Kranthi KR, Kranthi S, Ali S, Banerjee SK (2000) Resistance to Cry1AC -endotoxin of Bacillus thuringiensis in a laboratory selected strain of Helicoverpa armigera (Hubner). Curr. Sci 78:1001-1004

Muhammad IS, Muhammad A, Mansoor UH, Muhammad AK (2019) Efficacy of Cry1Ac toxin from Bacillus thuringiensis against the beet armyworm, Spodoptera exigua (Hubner) (Lepidoptera: Noctuidae). Egypt J Biol Pest Control 29:55

Roh JY, Jae YC, Ming SL, Byung RJ, Yeon HE (2007) Bacillus thuringiensis as a specific, safe and effective tool for insect pest control. J Microbiol Biotechnol 17:547-559

Sanda NB, Sunusi M, Hamisu HS, Wudil BS, Sule H, Abdullahi AM (2018) Biological invasion of tomato leaf miner, Tuta absoluta (Meyrick) in Nigeria: problems and management strategies optimization: a review. Asian Jour Agri and Hort Res 1(4):1-14

Sanyasi D, Govind TG (2011) Field evolved resistance to Bt toxin Cry1Ac in the pink bollworm, Pectinophora gossypiella (Saunders) (Lepidoptera: Gelechiidae) from India. Pest Manag Sci 67:898-903

Sayyed AH, Haward R, Herrero S, Ferre J, Wright DJ (2000) Genetic and biochemical approach for characterization of resistance to Bacillus thuringiensis toxin Cry1Ac in a field population of the diamondback moth, Plutella xylostella. Appl Environ Microbiol 66:1509-1516

Shasank PR, Chandrasekhar K, Meshram SK (2015) Occurrence of Tuto absoluta (Lepidoptera: Gelechiidae) an invasive pest in India. Ind J Entomol 77(4):323-329

Silva GA, Picanco MC, Bacci C, Rosado GRNC (2011) Control failure likelihood and spatial dependence of insecticide resistance in the tomato pinworm, Tuta absoluta. Pest Manag Sci 67:913-992

Srinivasan G, Dilipsundar N (2019) Bioefficacy of insecticides against invasive pest of tomato pinworm, Tuta absoluta (Meyrick, 1917). Ann Plant Prot Sci 27(2): 185-189

Stepanova TV, Baryshnikova ZF, Chirkov MV, Zhimerikin BN, Ryabchenko NF (1996) Bacillus thuringiensis strains exhibiting multiple activity against a wide range of insects. Biotechnolo giva 12:17-22

Tabashnik BE, Carriere $Y$ (2017) Surge in insect resistance to transgenic crops and prospects for sustainability. Nature Biotechnology. 35(10):926-935

Tropea Garzia G, Siscaro G, Biondi A, Zappala L (2012) Tuta absoluta, a South American pest of tomato now in the EPPO region: biology, distribution and damage. EPPO Bulletin 42:205-221

Youssef NA, Hassan GM (2013) Bioinsecticide activity of Bacillus thuringiensis isolates on tomato borer, Tuta absoluta (Meyrick) and their molecular identification. Afr J Entom 12(23):3699-3709

\section{Publisher's Note}

Springer Nature remains neutral with regard to jurisdictional claims in published maps and institutional affiliations. 